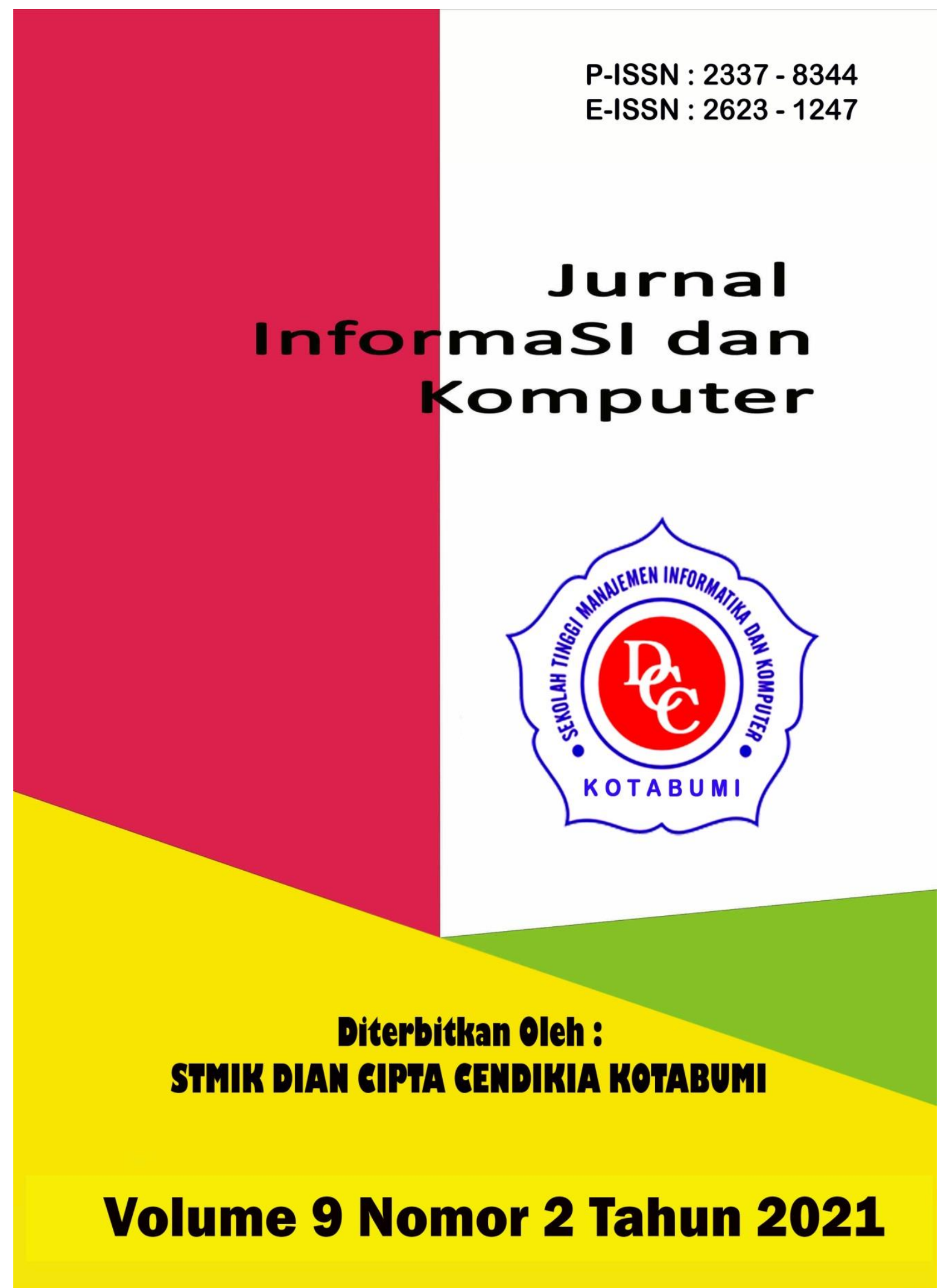




\section{Penerbit}

\section{Lembaga Penelitian STMIK Dian Cipta Cendikia Kotabumi}

Hak atas naskahh/tulisan tetap berada pada penulis, isi diluar tangung jawab penerbit dan Dewan Penyunting 


\section{PENGANTAR REDAKSI}

Puji syukur dipanjatkan kehadirat Tuhan Yang Maha Esa, atas karunia dan limpahan rahmatNYA jualah Jurnal Informasi dan komputer (JIK) STMIK Dian Cipta Cendikia Kotabumi ini dapat terwujud.Jurnal Informasi dan Komputer (JIK) yang terbit dua (2) kali dalam setahun ini merupakan suatu wadah untuk penyebar luasan hasil-hasil penelitian, studi pustaka, karya ilmiah yang berkaitan dengan Informasi dan Komputer khususnya bagi dosen-dosen STMIK Dian Cipta Cendikia Kotabumi serta umumnya para cendikiawan, praktisi, peneliti ilmu Informatika dan Komputer.

Harapan, dengan diterbitkannya Jurnal Informasi dan Komputer (JIK) ini sebagai salah satu bentuk sumbangan pemikiran dalam pengembangan ilmu informatika dan komputer yang berkaitan dengan kajian-kajian di bidang tekhnologi Informatik, Komunikasi Data dan Jaringan Komputer, perancangan dan Rekayasa Perangkat Lunak, serta ilmu-ilmu yang terkait dengan bidang Informasi dan Komputer lainnya.

Berkenaan dengan harapan tersebut, kepada para peneliti, dosen dan praktisi yang memiliki hasil-hasil penelitian, kajian pustaka, karya ilmiah dalam bidang tersebut diatas, dengan bangga redaksi Jurnal Informasi dan Komputer (JIK) menerima naskah ringkasan untuk dimuat pada jurnal Informasi dan Komputer (JIK) STMIK Dian Cipta Cendikia Kotabumi dengan berpedoman pada penulisan naskah jurnal sebagaimana dilampirkan pada halaman belakang (Bagian kulit dalam) buku jurnal ini.

Mutu dari suatu jurnal ilmiah tidak hanya ditentukan oleh para pengelolanya saja, tetapi para penulis dan pembaca jualah yang mempunyai peranan besar dalam meningkatkan mutu jurnal Informatika dan Komputer ini. Merujuk pada realita ini kamu sangat mengharapkan peran aktif dari peneliti untuk bersama-sama menjaga dan memelihara keberlangsungan dari jurnal Informasi dan Komputer STMIK Dian Cipta Cendikia Kotabumi ini. Yang juga tidak kalah pentingnya dari partisipasi tersebut diatas, adalah saran dan kritik yang membangun dari pembaca yang budiman agar kiranya dapat disampaikan langsung kepada redaksi JIK. Saran dan kritik yang membangun akan dijadikan masukan dan pertimbangan yang sangat berarti guna peningkatan mutu dan kualitas Jurnal Informasi dan Komputer STMIK Dian Cipta Cendikia Kotabumi.

Tak lupa diucapkan terima kasih yang tak terhingga atas perhatian dan kerjasama dari semua pihak yang tak dapat disebutkan satu persatu hingga dapat diterbitkan nya Jurnal Informasi dan Komputer (JIK) STMIK Dian Cipta Cendikia Kotabumi. Semoga apa yang telah diperbuat untuk kebaikan akan menjadi amal ibadah, amin.

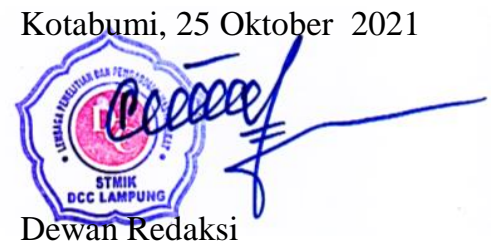




\section{JURNAL INFORMASI DAN KOMPUTER}

Volume 9 Nomor 2 Oktober 2021

Jurnal Informasi dan Komputer merupakan Sarana informasi ilmu pengetahuan, Tekhnologi dan Komunikasi yang berupa hasil penelitian, tulisan ilmiah, Ataupun studi pustaka. Jurnal ini terbit dua kali setahun pada bulan April dan Oktober. Berisi hasil penelitian ilmiah di bidang informatika yang bertujuan untuk menghubungkan adanya kesenjangan antar kemajuan teknologi dan hasil penelitian. Jurnal ini di terbitkan pertama kali pada tahun 2013.

Penanggung Jawab:

Ketua STMIK Dian Cipta Cendikia Kotabumi

\section{Pembina:}

Ketua STMIK Dian Cipta Cendikia Kotabumi Ketua Lembaga Penelitian STMIK Dian Cipta Cendikia Kotabumi

\section{Pimpinan Redaksi}

Dwi Marisa Efendi,.S.Kom.,M.Ti

\section{Redaksi pelaksana}

Rustam,.S.Kom,.M.Ti (STMIK Dian Cipta Cendikia Kotabumi)

Nurmayanti M.Kom (STMIK Dian Cipta Cendikia Kotabumi)

Sukatmi,.S.Kom., M.Kom (AMIK DCC Bandar Lampung)

Sampurna Dadi Riskiono,M.Kom (Universitas Teknokrat Indonesia)

Ifo Wahyu Pratama,S.Kom.,M.Ti(AMIK MASTER Lampung)

\section{Mitra Bestari}

Dr. RZ. ABDUL AZIZ, ST., MT (Institut Informatika dan Bisnis Darmajaya)

Dr. Dadang Sudrajat, S.Si, M.Kom (STMIK IKMI Cirebon)

Dr. Septafiansyah Dwi Putra, S.T., M.T (Politeknik Negeri Lampung)

Dr. Evi Grativiani, S.E., M.S.I (Universitas Sebelas Maret)

Rohmat Indra Borman ( Universitas Teknokrat Indonesia )

Ferry Wongso, S.KOm., M.Kom ( STMIK Darma Pala Riau)

Ferly Ardhy, S.Kom., M.Ti ( Universitas Aisyah Pringsewu )

Firmansyah, S.E., M.Si (STMIK Darma Pala Riau)
Amarudin (Universitas Teknokrat Indonesia)

Didi Susianto, S.T., M.Kom (AMIK Dian Cipta Cendika Bandar Lampung)

Alhibarsyah, St., M.Kom (STMIK Tunas

Bangsa Bandar Lampung)

Kemal Farouq Mauladi, S.Kom .M.Kom (Universitas Islam Lamongan)

Rima Mawarni, M.Kom ( STMIK Dian Cipta Cendikia Kotabumi)

Wira Jaya Hartono, S.Pd., M.Pd ( STMIK Darma Pala Riau)

Penerbit : STMIK Dian Cipta Cendikia Kotabumi Bekerja Sama Dengan LPPM STMIK Dian Cipta Cendikia Kotabumi.

\section{Alamat Redaksi/Penerbit:}

Jl. Negara No. 3 Candimas Kotabumi Lampung Utara

No Telpon/Fax 072423003

Email : 1ppm-stmik@dcc.ac.id 


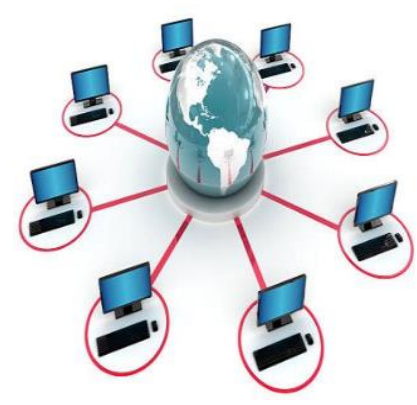

\section{JURNAL INFORMASI DAN KOMPUTER VOL. 9 NO. 2 THN. 2021}

\section{DAFTAR ISI}

Halaman

Sistem Informasi Akuntansi Persedian Barang Berbasis Web Pada Lembaga

Permasyarakatan Kelas II A Banceuy Bandung : "Kelompok Tani Desa Banjar Kertarahayu” Teuku Rian Hardiyansyah, Fatia Salsa Azzahra (Politeknik Piksi Ganesha Bandung ${ }^{1,2}$ ).

Penerapan Finite State Automata Pada Vending Machine Penjual Obat Non Resep

Dokter Dan Keperluan Medis

Eko Supriyanto $^{1}$, Angga Ardiansyah ${ }^{2}$, Frieyadie $^{3}$, Sri Rahayu ${ }^{4}$, Windu Gata ${ }^{5}$

(Universitas Nusa Mandiri ${ }^{12}$ )

Sistem Pendukung Keputusan Untuk Menentukan Kelayakan Pengajuan Sertifikasi Guru Dengan Metode Simple Additive Weighting (Studi Kasus : Ma Al Muhajirin Janti Jogoroto Jombang)

Budiman, umam baharudin, winarti

(Universitas Darul 'Ulum Jombang)

Perancangan Infrastruktur Domain Name Server Lokal Menggunakan Ubuntu Server 16.04

Pada PT. Xyz

Zaenal Mutaqin Subekti, Hendra Setiawan, Satria, Widia Murni Wijaya,

Aliy Hafiz, Warsudi

(STMIK Bani Saleh, Universitas Negeri Yogyakarta, AMIK Dian Cipta Cendikia,

STMIK MIC CIkarang)

Perancangan Sistem Informasi Idea Proposal (Ip) Berbasis Web Pada Pt. Paxel Algorita Unggul

Julian Murhan Sahputra, Indah Purnamasari

(Universitas Nusa Mandiri ${ }^{12}$ )

Sistem Pendukung Keputusan Untuk Menentukan Ekstrakurikuler Atletik

Berdasarkan Bakat Siswa Menggunakan Metode Profile Matching

Agnes Basuki, Petrus Sokibi, Tiara Eka Putri

(Universitas Catur Insan Cendekia)

Penerapan Algoritma K-Means Untuk Pengelompokan Usia Calon Penerima Vaksin

Di Kab. Ngawi

Irna Yuniarfi, Saifulloh

(Universitas PGRI Madiun $^{12}$ )

System Penilaian Seleksi Calon Karyawan Baru Menggunakan Metode Simple Additive Weighting (SAW) Di PT.TNA

Anik Sri Wahyuningsih, Yudhi Firmansyah

(Universitas Panca Sakti Bekasi ) 
Perancangan Sistem Informasi Pembayaran SPP Menggunakan Framework Laravel Ichwan Habib Moudi

(Universitas Panca Sakti Bekasi)

Implementasi Algoritma K-Means Dan Algoritma Apriori Optimasi Kinerja Ecu

(Study Kasus Mobil Avanza Dan Xenia)

Sigit Mintoro' Asep Afandi

(STMIK Dian Cipta Cendikia Kotabumi)

Sistem Pakar Penyakit Buah Kakao Untuk Peningkatan Hasil Panen Kakao Menggunakan

Metode Case Base Reasoning (CBR) Berbasis Web Mobile

Aliy hafiz, Verawati

(AMIK Dian Cipta Cendikia,Bandar Lampung)

Penerapan Metode Rapid Application Develomment (RAD) Dalam Pengembangan

Sistem Pemesanan Menu Berbasis Android

Aris Baihaqi, Tumini

(Fakultas Sains dan Teknologi ${ }^{1,2}$ )

Rancang Bangun Sistem Informasi Geografis Pariwisata Di Lampung Timur

Sukatmi, Rexa Alfa Rizi

(AMIK DCC Bandar Lampung ${ }^{12}$ )

Implementasi Psak No. 45 Pada Proses Penyusunan Laporan Keuangan Menggunakan

M.S. Excel Dan Aplikasi Accurate Accouting Pada STMIK Bani Saleh

Marhakim, Willy Adam

(STMIK Bani Saleh ${ }^{12}$ )

Sistem Prediksi Harga KOPI LAMBAR ( Lampung Barat) Dengan Metode

Backpropagation, dan Double Exponential ( Studi Kasus BUMDES )

Supriyanto, Dwi marisa Efendi,Rhomadhon

(STMIK Dian Cipta cendikia Kotabumi ${ }^{1-}$ )

Sistem Informasi Pemasaran Produk Umkm Berbasis Web Pada Kecamatan Bumi

Nabung Lampung Tengah

Yuli Syafitri, Agus Prasetyo, Reni Astika

(AMIK Dian Cipta Cendikia Bandar Lampung)

Rancang Bangun Aplikasi Pembelajaran Aksara Lampung Berbasis Android

Ferly Ardhy, Hendra Syahrobi

(Universitas Aisyah Pringewu ${ }^{1,}$ STMIK Dian Cipta Cendikia ${ }^{2}$ )

Sistem Pakar Diagnosa Penyakit Kulit Pada Balita Menggunakan Metode Naïve

Bayes Dan Forward Chaining Studi Kasus Puskesmas Cempaka Sungkai Selatan

Sidik Rahmatullah, Rima Mawarni

(STMIK Dian Cipta Cendikia Kotabumi ${ }^{12}$ )

Rekayasa Perangkat Lunak Perhitungan Harga Pokok Produksi Metode

Full Costing Pada Umkm Mitra Cake Di Bandar Lampung

Pitrawati, Arif Sanjaya

(AMIK Dian Cipta Cendikia, Bandar Lampung) 
Rancang Bangun Sistem Ujian Online Menggunakan Algoritma Cosine Similarity

Berbasis Web

Haryono, Zaenal Mutaqin Subekti, Widiyawati, Hidayatullah

(STMIK Bani Saleh ${ }^{1234}$ )

Model Aplikasi Helpdesk Ticketing System Berbasis Web Menggunakan Metode Rad

Indra Permana

Pattern Recognition Tulisan Tangan Huruf Hijaiyah Menggunakan Metode

Convolutional Neural Network (CNN)

Mufassiril Abror, Nopiyanto

(Universitas Panca Sakti Bekasi ${ }^{12}$ )

Aplikasi Sistem Informasi Keuangan Berbasis Android Di Perumahan Taman

Karang Bahagia

Melda Ayulestari

(Universitas Panca Sakti Bekasi)

Audit Pelayanan Sistem Rujukan Online Puskesmas Menggunakan Framework COBIT 5.0

Nurmayanti, Merri Parida, Ngajiyanto, Ina Anzalna

(STMIK Dian Cipta Cendikia Kotabumi ${ }^{1234}$ )

Perancangan Sistem Informasi Pengolahan Data Nilai Siswa Berbasis Web

Erin Ermawati, Anik Sri Wahyuningsih

(Fakultas Sain dan Teknologi, Universitas Panca Sakti Bekasi ${ }^{12}$ )

Pengembangan Sistem Pelaporan Data Hasil Inspeksi Barang Berbasis Web

Siska Putriani

(Universitas Pancasakti Bekasi)

Penerapan Extreme Programming Dalam Perancangan Aplikasi Web Food Market

Tumini, Hilman Septiana

(Fakultas Sains dan Teknologi Universitas Panca Sakti Bekasi ${ }^{1,2}$ )

Sistem Pencarian Barang Berbasis Website Menggunakan Php Dan Mysql

Studi Kasus PT. Surya Technology Industri Sulaeman

(Universitas Panca Sakti Bekasi)

Implementasi Metode Prototype Pada Sistem Peminjaman Alat Kerja Berbasis Web

Di PT SK Metalindo

Ali Mulyanto, Arjun Gunawan

(Univeritas Panca Sakti Bekasi)

Aplikasi Tata Cara Wudhu Menggunakan Teknologi Augmented Reality

Sebagai Media Pembelajaran Di TK Al Fatih

Ahmad Yakub , Idarul Fadli

(Universitas Panca Sakti Bekasi ${ }^{12}$ )

Sistem Pakar Diagnosa Penyakit Ayam Petelur Menggunakan Metode Certainty Factor

Berbasis Web Mochammad

Taufiq Hidayat, Ali Mulyanto

(Universitas Panca Sakti Bekasi ${ }^{12}$ ) 
Penerapan Metode Prototyping Dalam Perhitungan Hasil Produksi Menggunakan

Arduino Uno R3 Dan Php Di PT. Indonesia Epson Industry

Amandha Aulia, Ajar Rohmanu

(Universitas Panca Sakti Bekasi ${ }^{12}$ )

System Pendukung Keputusan Penentuan Guru Teladan Dengan Metode Profile Matching

Hasbulloh, Agmawarnida

(Universitas Panca Sakti Bekasi ${ }^{1,2}$ )

Implementasi Waterfall Method Pada Aplikasi Buku Induk Siswa Berbasis Web

Idam Holid, Yogie Krisnayadi

(Universitas Panca Sakti ${ }^{12}$ )

Pengembangan Text To Speech Media Pembelajaran Untuk Pengenalan

Anggota Tubuh Manusia Kelas V Sekolah Dasar

Juwanda Saputra, Ali Mulianto

(Teknik Infomratika Fakulutas Sains dan Teknologi ${ }^{12}$ )

Perancangan Sistem Peminjaman Barang Berupa Aset Tetap Berbasis Web

Pada Lembaga Permasyarakatan Kelas II A Banceuy Bandung

Guntur Salasa Priambodo, Perwito, Candra Mecca Sufyana

(Politeknik Piksi Ganesha Bandung ${ }^{1,2,3}$ )

Metode Pemilihan Karyawan Terbaik Sebagai Penentu Goodwill Perguruan Tinggi

Dengan Menggunakan Metode Topsis (Studi Kasus Perguruan Tinggi Di Lampung Utara)

Dwi Sartika, Pakarti Riswanto

(STMIK Dian Cipta Cendikia Kotabumi)

Sistem Pendukung Keputusan Pemilihan Merek Smartphone Menggunakan

Metode Analytical Hierarchy Process (AHP)

Ade Kiki Fatmawati, Muhammad Sultan Raflie, Norma Yunita

(Universitas Nusa Mandiri ${ }^{123}$ )

Pattern Recognition Aksara Lampung Menggunakan Algoritma Neural Network

Metode Analytical Hierarchy Process (AHP)

Nopiyanto, Rahmadi

(Universitas Panca Sakti Bekasi) 


\title{
APLIKASI TATA CARA WUDHU MENGGUNAKAN TEKNOLOGI AUGMENTED REALITY SEBAGAI MEDIA PEMBELAJARAN DI TK AL FATIH
}

\author{
Ahmad Yakub ${ }^{1}$, Idarul Fadli ${ }^{2}$ \\ Universitas Panca Sakti Bekasi ${ }^{12}$ \\ J1. Kapten Sumantri No 16 Cikarang, Kab. Bekasi 17530, Indonesia \\ e-mail: ahmad.yakub@president.ac.id ${ }^{1}$, fadliidarul23@gmail.com²
}

\begin{abstract}
ABSTRAK
Seiring perkembangan teknologi yang pesat, berkembangnya teknologi juga ikut mempengaruhi dalam bidang pendidikan. Namun belum terlalu dimanfaatkan dalam bidang pendidikan yang membutuhkan alat peraga. Augmented Reality (AR), adalah teknologi dengan konsep menggabungkan dimensi dunia nyata dengan dimensi dunia maya yang di tampilkan secara realtime. Hal ini dilakukan dengan cara menggambar objek tiga dimensi pada marker, yakni sebuah pola yang bersifat unik dan dapat dikenali oleh aplikasinya. Smartphone memungkinkan pengembangan aplikasi Augmented Reality dengan mudah serta dapat diakses oleh banyak pengguna. Augmented Reality dapat dimanfaatkan dalam berbagai bidang salah satunya adalah sebagai sarana pendidikan untuk anak. Augmented Reality dapat digunakan untuk menciptakan sebuah lingkungan pembelajaran yang lebih interaktif dimana anak - anak dapat berinteraksi langsung dengan obyek dunia maya sehingga anak - anak pun dapat bermain sambil belajar. Sebelum melaksanakan ibadah shalat menurut Jumhur Ulama' mengatakan bahwa melakukan wudhu dianjurkan sebelum melakukan ibadah thawaf di Ka'bah, memegang mushaf Al - Qur'an dan ibadah lainnya. Pada wudhu terkandung sebuah hikmah yang mengisyaratkan kepada kita bawah hendaknya seorang muslim memulai ibadah dan kehidupannya dengan kesucian lahir batin. Oleh karena itu, umat muslim harus mengetahui tata cara berwudhu yang sesuai syariat islam. Dalam penelitian ini penulis akan membuat media pembelajaran tata cara wudhu menggunakan teknologi Augmented Reality, Aplikasi yang digunakan yaitu, Blender Untuk membuat model 3D karakter manusia beserta animasi gerakan wudhu dengan metode Pose to pose, CorelDraw untuk membuat marker dan desain tampilan aplikasi, Unity 3D untuk membuat aplikasi Augmented Reality berbasis android. Hasil penelitian ini menggunakan metode Multimedia Development Life Cycle (MDLC).
\end{abstract}

Kata kunci : Augmented Reality, Wudhu, Blender, CorelDraw, Multimedia Development Life Cycle

\section{ABSTRACT}

As the development of technology that is rapidly growing technology also participated influence in the field of education. But not too exploited in the field of education that need a tool props. Augmented Reality $(A R)$ is the technology with the concept of combining the dimensions of the world real to the dimensions of the world maya which in show in real time. It is in doing by way of drawing objects of three dimensions on a marker, which is a pattern that is unique and can be recognized by the application. Smartphone allows the development of applications Augmented Reality with mud ah, and may be accessed by many users. Augmented Reality can be used in various fields, one of which is as a means of education for children. Augmented Reality can be used to create an environment of learning that is more interactive in which the child - the child can interact directly with the object world virtual so that the child - the child was able to play while learning. S Before the implement of worship to pray according to jumhur Ulama' said that perform ablution is recommended before doing worship tawaf at the Ka'bah, holding the Mushaf Al - Qur'an and worship other. At ablution contained a wisdom that suggests to us down should a Muslim start the worship and life to the sanctity of birth inward. By because the people of Muslim should know the procedure how to perform ablutions are appropriate Shari'a of Islam. In the study 's authors will make media learning system how to perform ablution using the technology of Augmented Reality, applications are used, namely, Blender to create models of $3 D$ character man along with animated motion ablution with methods pose to pose, CorelDraw to create a 
marker and design of display applications, Unity 3D for create an Android -based Augmented Reality application. The results of this study used the Multimedia Development Life Cycle (MDLC) method.

\section{Keywords - Augmented Reality; Wudhu; Blender; CorelDraw; Multimedia Development Life Cycle}

\section{PENDAHULUAN}

Selain dilakukan sebelum melaksanakan ibadah shalat menurut Jumhur Ulama' mengatakan bahwa melakukan wudhu dianjurkan sebelum melakukan ibadah thawaf di Ka'bah, memegang mushaf $\mathrm{Al}$ - Qur'an dan ibadah lainnya. Pada wudhu terkandung sebuah hikmah yang mengisyaratkan kepada kita bawah hendaknya seorang muslim memulai ibadah dan kehidupannya dengan kesucian lahir batin. Oleh karena itu, umat muslim harus mengetahui tata cara berwudhu yang sesuai syariat islam. Buku merupakan sebuah media atau alat informasi yang mungkin sudah ada sejak ratusan tahun yang lalu, selain berfungsi sebagai tempat menyimpan atau menyampaikan berbagai informasi, baik bersifat umum maupun khusus. Buku merupakan salah satu media pembelajaran yang banyak digunakan dan buku digunakan sebagai alat berkomunikasi oleh guru-guru maupun orang tua terhadap anak-anak, misalkan seperti jenis buku panduan mengenai tata cara pengambilan wudhu. Tetapi penyampaian informasi pada buku panduan pengambilan wudhu hanya berupa teks dan gambar-gambar 2D. Pembelajaran tata cara wudhu masih menggunakan cara konvensional, murid melihat buku panduan dan guru menjelaskan bagaimana tata cara pengambilan wudhu.

Menurut bahasa, Wudhu artinya Bersih dan Indah. sedangkan menurut istilah (syariah islam) artinya menggunakan air pada anggota badan tertentu dengan cara tertentu yang dimulai dengan niat guna menghilangkan hadast kecil. Wudhu merupakan salah satu syarat sahnya sholat (orang yang akan sholat, diwajibkan berwudhu lebih dulu, tanpa wudhu shalatnya tidak sah.

Augmented Reality (AR) adalah suatu karakter yang memasukkan objek virtual 3D ke dalam lingkungan nyata. AR mengizinkan penggunanya untuk berinteraksi secara realtime (Pakarya,Dkk 2019). Penggunaan AR saat ini telah melebar keberbagai aspek dalam kehidupan kita dan diproyeksikan akan mengalami perkembangan yang sangat signifikan. Hal ini dikarenakan penggunaan AR sangat menarik dan memudahkan penggunaannya dalam mengerjakan sesuatu hal, seperti contohnya pada strategi pemasaran penjualan rumah kepada konsumen.

Media pembelajaran mengenai tata cara wudhu saat ini banyak ditemui dipasaran, seperti buku. Namun pada buku penyampaian gerakan wudhu hanya berupa teks atau gambar diam saja.Selain buku, media pembelajaran lain seperti audio tape recorder dan CD interaktif. Keduanya sudah berbasis multimedia, namun masing-masing media pembelajaran tersebut masih memiliki kekurangan. Dalam audio tapi recorder pengguna hanya dapat mendengarkan suara saja selain itu juga dibutuhkan tape sebagai alat pemutarnya. Begitu juga dengan $\mathrm{CD}$ interaktif yang juga membutuhkan komputer sebagai media interaksi. Dengan menggunakan penerapan sistem Argumented Reality informasi dapat diberikan melalui gambar bergerak, dan suara sehingga dapat meningkatkan minat dalam belajar. Terutama untuk anak-anak yang masih proses belajar perlu sebuah tuntunan dengan sesuatu yang menarik dan tidak memberikan rasa jenuh saat belajar (Pakarya,Dkk 2019).

Augmented Reality sangat berpotensial sebagai sarana edukasi. Salah satu keuntungan yang dapat diperoleh dari aplikasi AR untuk tujuan edukasi yaitu meningkatkan pehaman objek yang dipelajari. AR lebih efektif sebagai media pembelajaran lainnya, dibandingkan dengan media lain seperti buku, video, maupun penggunaan komputer biasa. Untuk itu AR bisa sangat berpotensi sebagai sarana edukasi.

\section{LANDASAN TEORI}

\subsection{Augmented Reality}

Augmented Reality (AR), adalah teknologi dengan konsep menggabungkan dimensi dunia nyata dengan dimensi dunia maya yang di tampilkan secara realtime. Hal ini dilakukan dengan cara 'menggambar' objek tiga dimensi pada marker, yakni sebuah 'pola' yang bersifat unik dan dapat dikenali oleh aplikasinya. 
Smartphone memungkinkan pengembangan aplikasi Augmented Reality dengan mudah serta dapat diakses oleh banyak pengguna. Augmented Reality dapat dimanfaatkan dalam berbagai bidang salah satunya adalah sebagai sarana pendidikan untuk anak. Augmented Reality dapat digunakan untuk menciptakan sebuah lingkungan pembelajaran yang lebih interaktif dimana anak - anak dapat berinteraksi langsung dengan obyek dunia maya sehingga anak - anak pun dapat bermain sambil belajar. Pada tugas akhir ini, dikembangkan sebuah katalog Augmented Reality yang ditujukan kepada para guru dan orang tua sebagai alat pembelajaran pengenalan situs warisan dunia. Dalam penelitian ini, digunakan aplikasi Canva untuk membuat katalog, Blender untuk membuat Model 3D bangunan, dan Unity untuk membuat aplikasi Augmented reality berbasis android. Diharapkan aplikasi beserta katalog ini selanjutnya bisa dikembangkan dan dapat memuat informasi yang lebih banyak dan dapat di gunakan diberbagai platformmented Reality. Augmented Reality adalah penggabungan benda-benda nyata dan maya di lingkungan nyata, berjalan secara interaktif dalam waktu nyata, dan terdapat integrasi antara benda dalam tiga dimensi, yaitu benda maya terintegrasi dalam dunia nyata. Penggabungan benda nyata dan maya dimungkinkan dengan teknologi tampilan yang sesuai, interaktivitas dimungkinkan melalui perangkatperangkat input tertentu, dan integrasi yang baik memerlukan penjejakan yang efektif. Berikut ini merupakan teknik penggunaan Augmented Reality beserta penjelasannya :

\section{Marker}

Marker merupakan salah satu metode yang digunakan pada Augmented Reality. Marker biasanya merupakan ilustrasi hitam dan putih persegi dengan batas hitam tebal dan latar belakang putih. Komputer akan mengenali posisi dan orientasi marker dan menciptakan dunia virtual 3 dimensi yaitu titik $(0,0,0)$ dan 3 sumbu yaitu X,Y,dan Z. Metode marker ini sudah lama dikembangkan sejak 1980-an dan pada awal 1990-an mulai dikembangkan untuk penggunaan augmented reality.

\section{Markerless}

Salah satu metode Augmented Reality yang saat ini sedang berkembang adalah metode Markerless Augmented Reality, dengan metode ini pengguna tidak perlu lagi menggunakan sebuah marker untuk menampilkan elemenelemen digital. Sekalipun dinamakan dengan markerless namun aplikasi tetap berjalan dengan melakukan pemindaian terhadap object, namun ruang lingkup yang dipindai lebih luas dibandingkan dengan Marker Augmented Reality. Seperti yang saat ini dikembangkan oleh perusahaan Augmented Reality terbesar di dunia Total Immersion dan Qualcomm, mereka telah membuat berbagai macam teknik Markerless Tracking sebagai teknologi andalan mereka, seperti Face tracking, Objek Tracking, Motion Tracking dan GPS Based Tracking.

\subsection{Corel Draw}

Corel Draw merupakan aplikasi yang menyediakan sejumlah besar fasilitas pemroses berbagai objek gambar/teks. Sistem corel draw dirancang untuk membentuk gambar ilustrasi dalam bentuk vector (objek gambar terbentuk dari informasi titik dan spesifikasi lokasi serta relasinya). Corel draw juga dapat digunakan untuk memproses objek gambar Bitmap (objek gambar yang dibentuk melalui titik dengan warna tertentu), seperti foto.

\subsection{Blender 3D}

Blender 3D adalah perangkat lunak sumber terbuka grafika komputer 3D. Perangkat lunak ini digunakan untuk membuat film animasi, efek visual, Model cetak 3D, aplikasi 3D interaktif dan permainan video. Blender 3D memiliki beberapa fitur termasuk pemodelan 3D, penteksturan, penyunting gambar bitmap, pengulangan, simulasi cairan dan asap, simulasi partikel, animasi, penyunting video, pemahat digital, dan rendering.

\subsection{Unity 3D}

Unity $3 D$ merupakan suatu aplikasi yang digunakan untuk mengembangkan game multi platform dan dapat juga digunakan untuk membuat animasi 3 dimensi yang didesain untuk mudah digunakan. Unity itu bagus dan penuh perpaduan dengan aplikasi yang profesional. Editor pada Unity dibuat degan user interface yang sederhana. Editor ini dibuat setelah ribuan jam yang mana telah dihabiskan 
untuk membuatnya menjadi nomor satu dalam urutan rankking teratas untuk editor game. Berikut ini adalah bagian-bagian dalam Unity :

\section{Asset}

Asset merupakan tempat penyimpanan dalam Unity, suara, gambar, video, tekstur, semua yang ingin dipakai dalam Unity disimpan didalam asset.

\section{Scenes}

Scenes adalah sebuah area yang diberikan konten-konten dalam game, seperti level, membuat menu, dsb.

\section{Game Objects}

Ketika sebuah barang didalam asset dipindahkan ke dalam scene, maka benda tersebut berubah menjadi game objects. Dimana benda tersebut bisa digerakan, diatur ukurannya dan diatur rotasinya.

\section{Components}

Components dapat dimasukan kedalam game objects untuk menciptakan reaksi baru, seperti collision, memunculkan partikel, dll. Intinya components membuat reaksi baru didalam game objects.

\section{Scripts}

Scripts yang dapat digunakan dalam Unity yaitu, javascripts, C\#. tetapi Unity tidak menyediakan cara untuk menggunakan scripts tersebut.

\section{Prefabs}

Prefabs adalah tempat untuk menyimpan satu jenis game objects, sehingga mudah untuk diperbanyak. Tujuan utama prefab adalah agar tidak perlu membuat objek yang sudah pernah dibuat.

\section{Vuforia}

Vuforia Software Development Kit (SDK). Yang dikembangkan oleh Qualcomm yang memungkinkan seorang developer untuk membuat aplikasi berbasis teknologi augmented reality. Dulu lebih dikenal dengan
QCAR (Qualcomm Company Augmented reality). Ditambah menggunakan teknologi Computer Vision untuk mengenali dan melacak gambar planar (Image Target) dan objek 3D sederhana seperti kotak secara real-time. Dengan support iOS, Android dan Unity3D, platform Vuforia mendukung para pengembang untuk membuat aplikasi yang dapat digunakan di hampir seluruh jenis smartphone. Pengembang juga diberikan kebebasan untuk mendesain dan membuat aplikasi yang mempunyai kemampuan antara lain :

a. Teknologi computer vision tingkat tinggi yang mengijinkan developer untuk membuat efek khusus pada mobile device.

b. Dapat mengenali lebih dari satu gambar.

c. Tracking dan Detection tingkat lanjut.

d. Solusi pengaturan database gambar yang fleksibel.

e. Penelitian Terdahulu

Penelitian teknologi Augmented Reality telah banyak dilakukan. Berikut penelitian yang di jadikan rujukan terkait dengan teknologi Augmented Reality.

Penelitian yang dilakukan Yoga Aprillion Saputra, yang berjudul Implementasi Augmented Reality (AR) Pada Fosil Purbakala Di Museum Geologi Bandung tujuan penelitian ini adalah memberikan informasi yang lebih menarik dan interaktif dari bagian-bagian kerangka fosil yang tidak utuh, sehingga pengunjung dapat mengetahui bentuk sebenarnya dari fosil purbakala dan juga mendapatkan infromasi mengenai fosil purbakala. Metode yang digunakan dalam pembuatan aplikasi Augmented Reality (AR) pada penelitian ini adalah metode berbasis marker (marker-based tracking). Hasil dari penelitian ini adalah aplikasi Augmented Reality (AR) Fosil purbakala yang membaca marker untuk memunculkan objek 3D tentang fosil purbakala sehingga pengunjung mendapatkan informasi tentang fosil purbakala dari bagian-bagian kerangka fosil yang tidak utuh.

Penelitian yang dilakukan Imanuel M Ngangi, Rizal Sengkey, dan Brave A. Sugiarso yang berjudul Katalog Augmented Reality Pengenalan Situs Bangunan Warisan Dunia Untuk Anak tujuan penelitian ini adalah menarik perhatian anak anak untuk 
mengenalkan situs warisan dunia dengan animasi 3D. Metode yang di gunakan dalam penelitian ini adalah metode Multimedia Development Life Cycle merupakan metode pengembangan yang terdiri dari enam tahap, yaitu : Concept, Design, Material Collecting, Assembly, Testing, Distribution. Aplikasi Pengenalan Situs Bangunan Warisan Dunia sebagai sarana edukasi anak, aplikasi ini dapat diterapkan sebagai salah satu bahan ajar di sekolah dan aplikasi ini dapat bermanfaat bagi para guru dan siswa dalam proses belajar tentang Situs Warisan Dunia.

Penelitian yang dilakukan Azalia Ananda Arinal, Virginia Tulenan, Agustinus Jacobus yang berjudul Pengembangan Aplikasi Tata Cara Wudhu Menggunakan Metode Markerless Augmented Reality tujuan penelitian ini adalah Tujuan dari aplikasi ini adalah meningkatnya keinginan orang-orang untuk mempelajari tata cara berwudhu yang baik dan benar. Metode yang digunakan dalam pembuatan aplikasi Augmented Reality (AR) pada penelitian ini adalah metode Multimedia Development Life Cycle. Hasil dari penelitian ini adalah Aplikasi Tata Cara Wudhu Menggunakan Metode Markerless Augmented Reality yang membaca marker untuk memunculkan objek 3D tentang tata cara wudhu.

\section{METODE PENELITIAN}

\subsection{Metode Penelitian}

Metode yang di gunakan dalam penelitian ini adalah metode Multimedia Development Life Cycle merupakan metode pengembangan yang terdiri dari enam tahapan. Enam tahapan metode MDLC dapat dilihat pada gambar 1, yaitu : Concept, Design, Material Collecting, Assembly, Testing, Distribution.

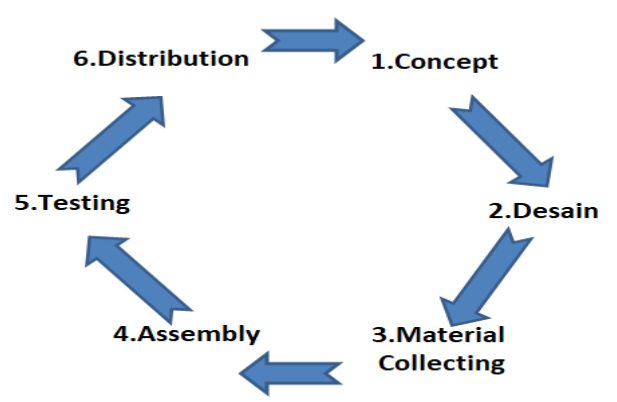

Gambar 1. Multimedia Develovment Life Cycle

\section{a. Concept (Konsep)}

Pada tahap ini pembuat atau pengembang merumuskan dasar-dasar dari proyek multimedia yang akan dibuat dan dikembangkan. Terutama pada tujuan dan jenis proyek yang akan dibuat. Pada tahap concept ini dilakukan untuk menentukan tujuan, konsep materi, konsep media pembelajaran serta siapa pengguna aplikasi.

\section{b. Design (Desain)}

Pada tahap ini pembuat atau pengembang proyek multimedia menjabarkan secara rinci apa yang akan dilakukan dan bagaimana proyek multimedia tersebut akan dibuat.

\section{e. Material Collecting (Pengumpulan Material)}

Pada tahap ini merupakan proses untuk pengumpulan segala sesuatu yang dibutuhkan dalam proyek, mengenai materi yang akan disampaikan, kemudian file-file multimedia sesuai dengan kebutuhan aplikasi seperti audio , objek 3D, dan gambar yang akan dimasukkan dalam penyajian proyek.

\section{f. Tahap assembly (pembuatan)}

Tahap assembly merupakan tahapan dimana materi-materi serta file-file multimedia yang sudah didapat kemudian dirangkai dan disusun sesuai desain dan akan digabungkan menjadi satu aplikasi.

\section{g. Testing (Pengujian)}

Tahap ini merupakan tahapan dilakukan testing atau pengujian setelah melewati tahap assemby. Pada tahap ini dilakukan uji coba seluruh komponen-komponen aplikasi secara keseluruhan agar diketahui jika terdapat error atau kesalahan.

\section{h. Distribution (Distribusi)}

Tahap ini adalah Tahap penggandaan dan penyebaran hasil kepada pengguna. Setelah aplikasi telah selesai diuji maka aplikasi sudah dapat didistribusikan. Pada tahap ini aplikasi akan disimpan pada suatu media penyimpanan kemudian di distribusikan kepada pengguna. 


\subsection{Alat dan Bahan}

Pada penelitian ini alat dan bahan yang digunakan yaitu:

Tabel 1. Alat dan bahan

\begin{tabular}{|l|l|}
\hline Hardware & Software \\
\hline Laptop Lenovo & Unity Versi \\
ideapad 110 & 2018.4.28f1 (64-bit) \\
\hline Xiaomi Redmi Note & Blender 3D Versi \\
4X & 2.93 .0 \\
\hline Oppo F11 Pro & Vuforia SDK \\
\hline Vivo Y20 & Corel Draw 2018 \\
\hline
\end{tabular}

\subsection{Lokasi Penelitian}

Penelitian ini dilakukan di TK Al Fatih Gramapuri yang berlokasi di Perum Gramapuri, Desa Sukajaya, Kecamatan Cibitung, Kabupaten Bekasi, Jawa Barat. TK Al Fatih Gramapuri merupakan suatu lembaga pendidikan non-formal yang bertujuan untuk mendidik anak usia dini.

\section{HASIL DAN PEMBAHASAN}

\subsection{Concept (Konsep)}

Pada tahap ini merupakan tahap awal dalam proses pembuatan aplikasi yaitu dengan menentukan tujuan pembuatan aplikasi, pengguna, dan fungsi dari aplikasi yang akan dibuat.

1. Penelitian ini bertujuan untuk membangun aplikasi pembelajaran tata cara wudhu dengan Augmented Reality berbasis Android agar menarik minat anak - anak dalam proses belajar.

2. Penggunaan teknologi Augmented Reality ini diharapkan agar pengguna mampu memahami gerakan tata cara wudhu dalam bentuk 3 Dimensi.

3. Android menjadi platform pada aplikasi ini agar mudah di gunakan. Aplikasi di jalankan cara mengarahkan kamera Augmented Reality pada marker yang telah di buat.

\subsection{Design (Perancangan)}

Tahap ini merupakan tahap pembuatan spesifikasi pada aplikasi yang akan dibuat seperti tampilan, bahan, model, dan arsitektur agar pembuatan aplikasi tertata dengan rapih. Perancangan pada aplikasi ini yaitu dengan membuat use case diagram, activity diagram dan membuat desain pada setiap scene yang meliputi desain tampilan, penempatan tombol dan teks.

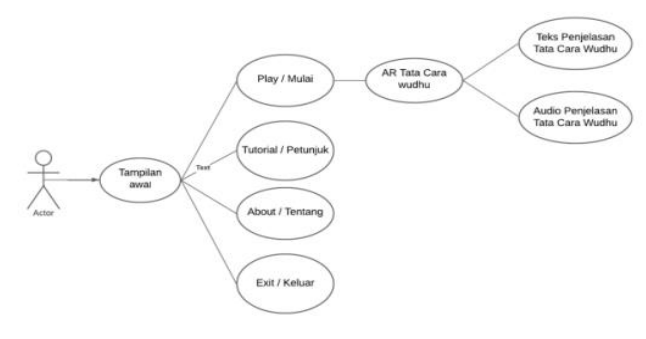

Gambar 2. Use Case Diagram

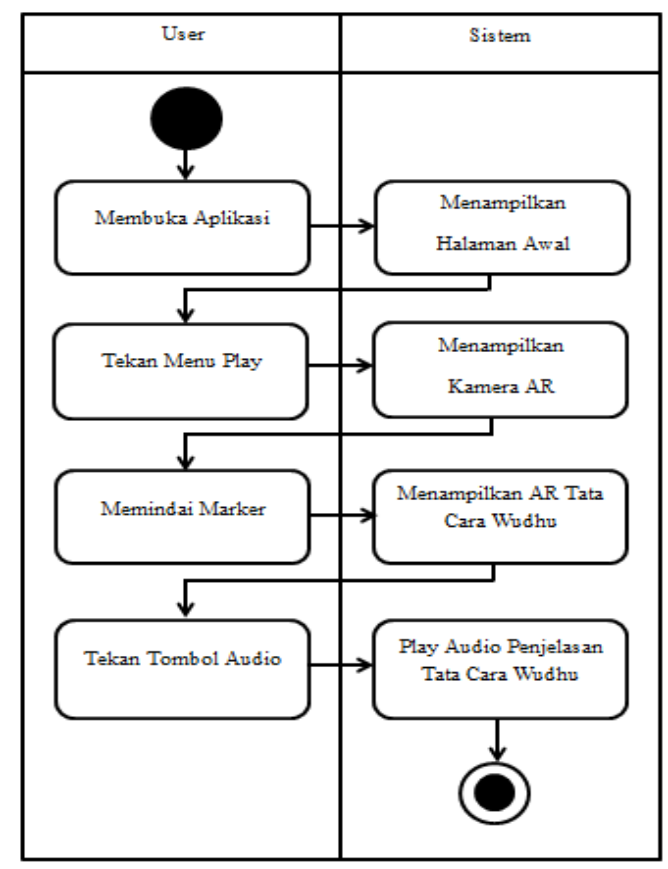

Gambar 3. Activity Diagram

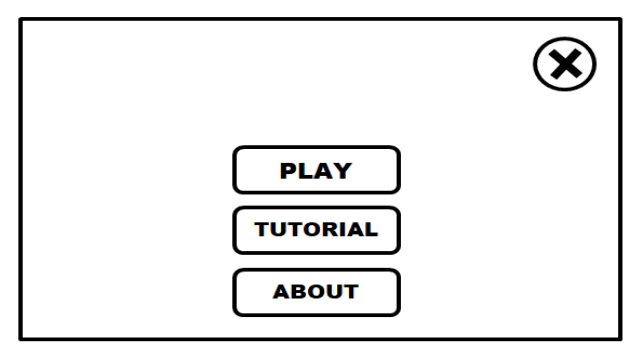

Gambar 4. Desain Menu Utama 


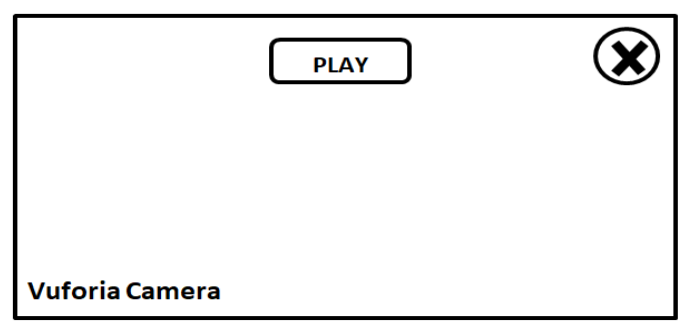

Gambar 5. Desain Tampilan Menu AR

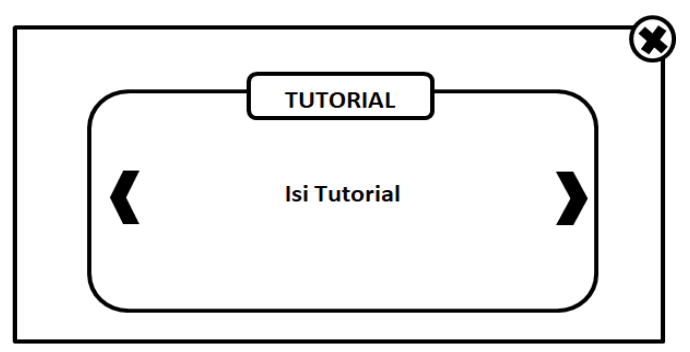

Gambar 6. Desain Tampilan Menu Tutorial

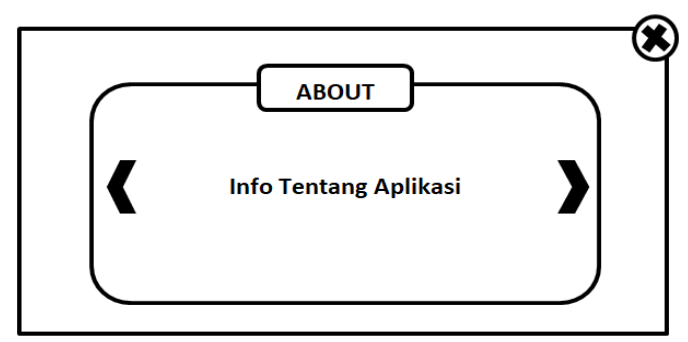

Gambar 7. Desain tampilan menu About

\subsection{Material Collecting (Pengumpulan Material)}

Merupakan tahap pengumpulan bahan material sebelum dilakukan tahap pembuatan aplikasi Tata Cara Wudhu, yang dirancang berupa objek $3 \mathrm{D}$, animasi gerakan pada objek 3D, teks, dan suara.

\subsection{Tahap Assembly (Pembuatan)}

Pada tahap ini dimana semua bahan material yang sudah dikumpulkan kemudian disusun dan dirangkai sesuai desain. Tahapan ini meliputi pembuatan objek 3D yang mampu bergerak, pembuatan marker, pembuatan katalog, dan pembuatan aplikasi.

Adapun pada tahap pembuatan aplikasi augmented reality ini antara lain sebagai berikut

\section{Pembuatan Objek 3D}

Tahap pertama dalam pembuatan objek 3D menggunakan Blender. Objek yang dibuat yaitu karakter manusia pada gambar 8 .

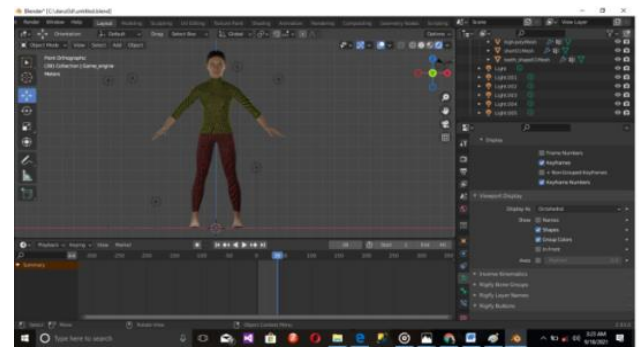

Gambar 8. Pembuatan Model 3D Karakter Manusia

\section{Rigging}

Merupakan proses pembuatan tulang pada objek $3 \mathrm{D}$ atau bisa di sebut proses pembuatan rantai tulang menggunakan Blender. Proses pembuatan bone atau tulang yaitu pada gambar 9.

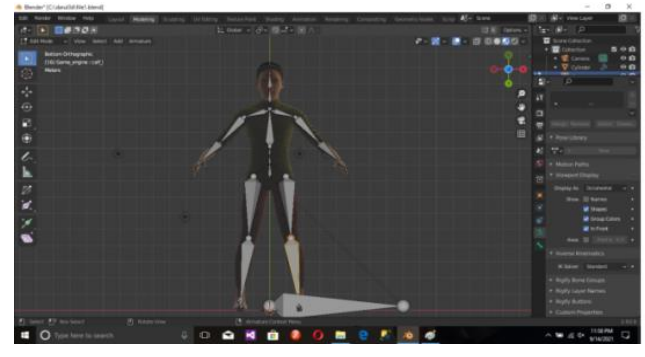

Gambar 9. Pembuatan Model Tulang

\section{Proses Animating}

Proses Animating merupakan proses penciptaan efek gerak pada objek 3D beberapa waktu dengan menggunakan metode Pose to pose. Animasi gerakan yang dibuat yaitu niat pada gambar 10, gerakan mencuci tangan pada gambar 11, gerakan berkumur pada gambar 12, gerakan mencuci lubang hidung pada gambar 13, gerakan mencuci muka pada gambar 14, gerakan mencuci lengan tangan pada gambar 15, gerakan mengusap kepala pada gambar 16, gerakan mengusap daun telinga pada gambar 17, gerakan mencuci kaki pada gambar 18, berdoa pada gambar 19. 


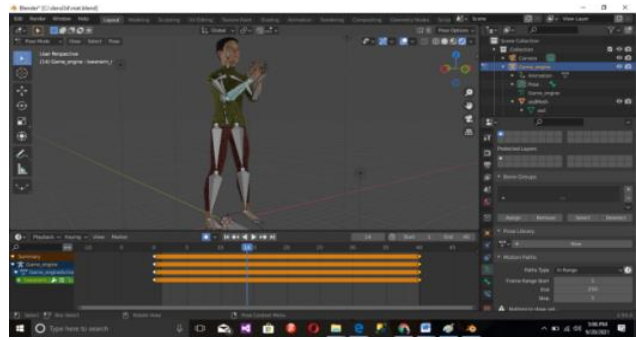

Gambar 10. Pembuatan Animasi Niat

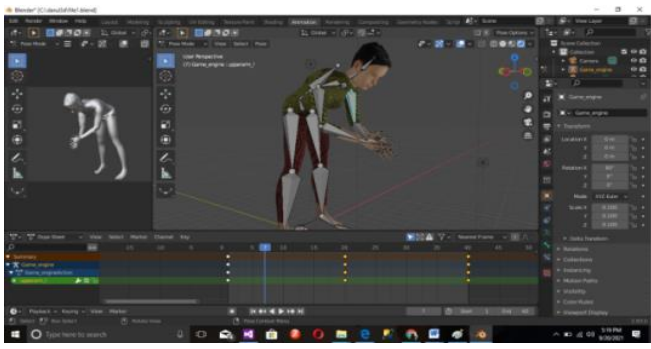

Gambar 11. Pembuatan Animasi Gerakan Mencuci Tangan

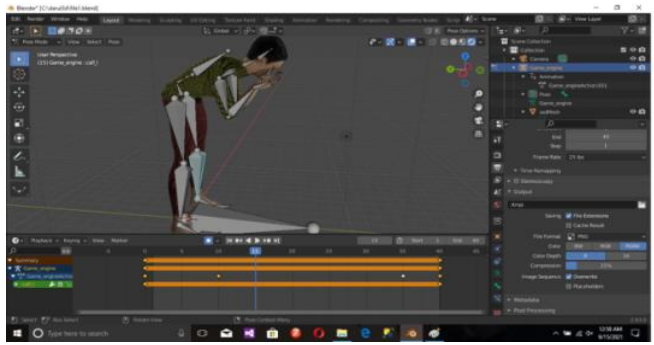

Gambar 12. Pembuatan Animasi Gerakan Berkumur

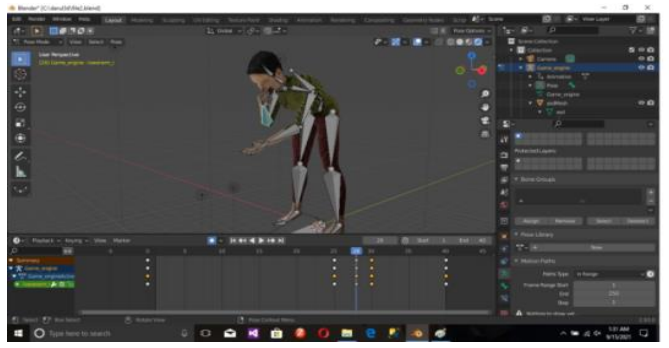

Gambar 13. Pembuatan Animasi Gerakan Mencuci Lubang Hidung

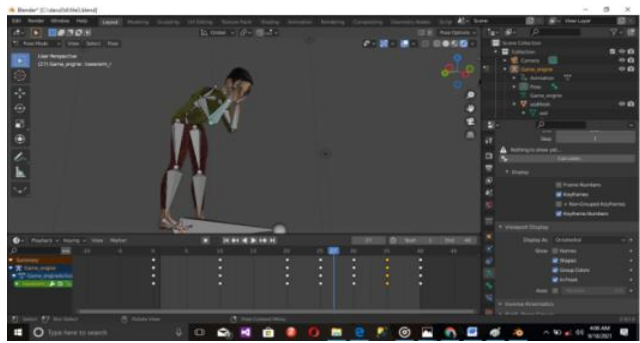

Gambar 14. Pembuatan Animasi Gerakan Mencuci Muka

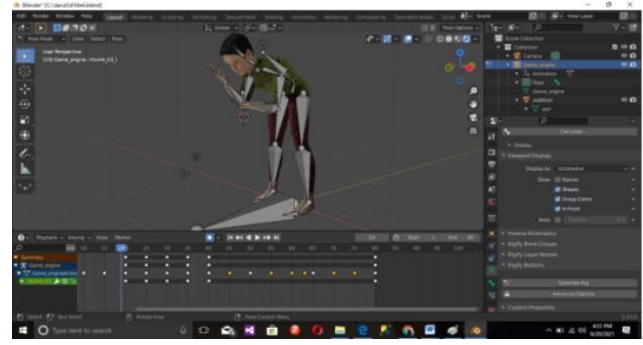

Gambar 15. Pembuatan Animasi Gerakan Mencuci Lengan Tangan

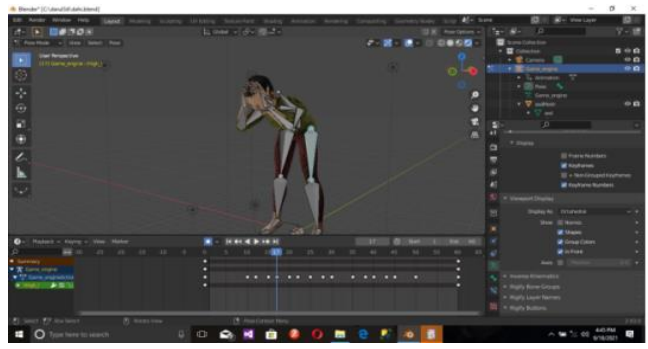

Gambar 16. Pembuatan Animasi Gerakan Mengusap Kepala

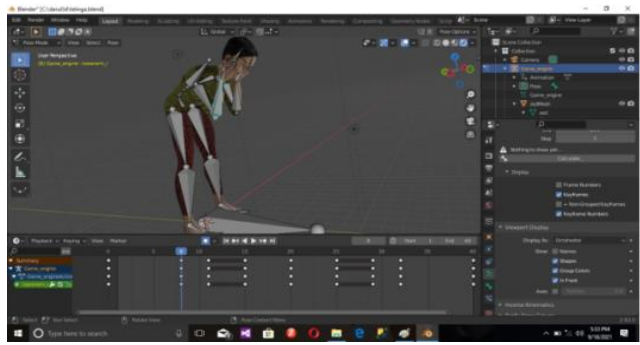

Gambar 17. Pembuatan Animasi Gerakan Mengusap Daun Telinga 


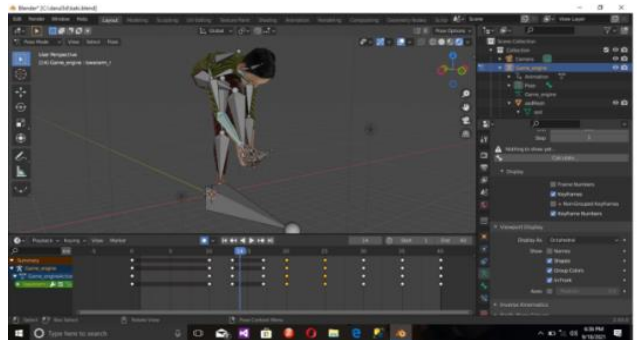

Gambar 18. Pembuatan Animasi Gerakan Mencuci Kaki

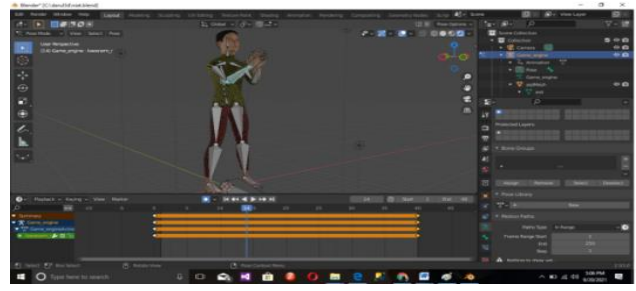

Gambar 19. Pembuatan Animasi Berdoa

\section{Pembuatan Marker}

Tahap ini merupakan pembuatan marker yang akan digunakan sebagai image target, yang berfungsi untuk memproyeksikan Model 3D dalam bentuk Augmented Reality. Marker ini dibuat menggunakan Vuforia, Pembuatan image target dan marker yaitu pada gambar 20 dan gambar 21.

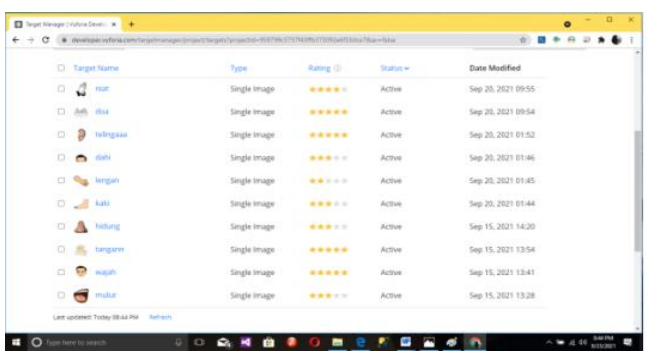

Gambar 20. Pembuatan Database Online Vuforia

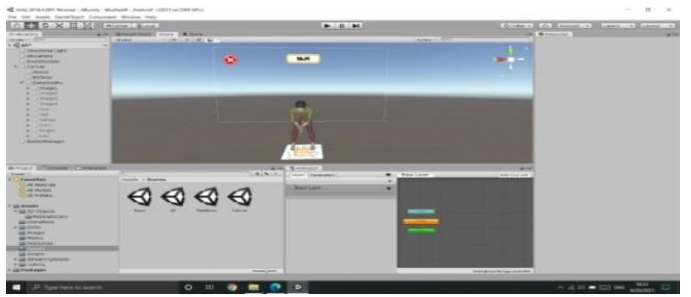

Gambar 21. Pembuatan Image Target \& Marker

\section{Pembuatan Aplikasi}

Proses pembuatan aplikasi menggunakan software Unity. Pembuatan model 3 dimensi karakter pada gambar 22, pembuatan menu utama menggunakan Unity pada gambar 23, tampilan menu utama pada gambar 24, tampilan menu tutorial pada gambar 25 , tampilan menu about pada gambar 26 .

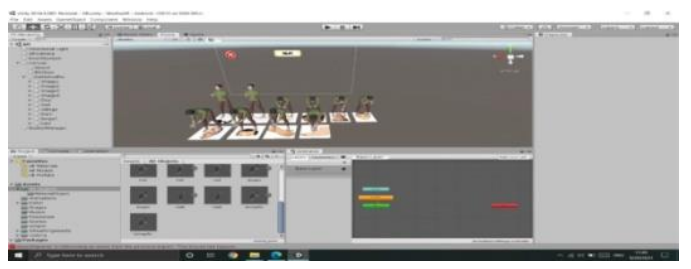

Gambar 22. Pembuatan Model 3D Karakter

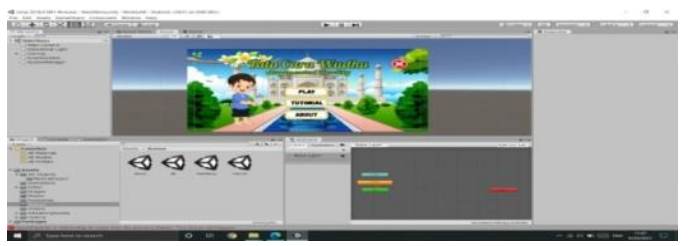

Gambar 23. Pembuatan Menu Utama

Pada pembuatan aplikasi terdapat beberapa tampilan yang akan di tampilkan pada aplikasi tata cara wudhu AR yaitu sebagai berikut :

\section{a. Tampilan Menu Utama}

Pada tampilan menu utama terdapat beberapa tampilan tombol antara lain, tombol Play, tombol tutorial, tombol about, dan tombol close. Pada tombol play digunakan untuk masuk ke tampilan augmented reality tata cara wudhu. Tombol tutorial digunakan untuk masuk ke tampilan cara penggunaan aplikasi. Tombol about digunakan untuk masuk ke tampilan informasi tentang aplikasi augmented reality ini. Tombol exit atau gambar silang digunakan untuk keluar dari aplikasi.

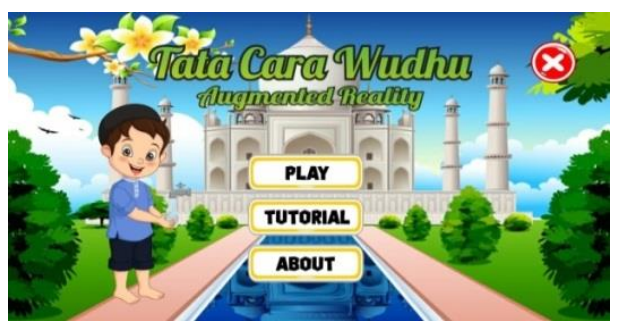

Gambar 24. Tampilan Menu Utama 


\section{b. Tampilan Menu Tutorial}

Pada tampilan ini terdapat informasi tentang cara menggunakan aplikasi augmented reality, tekan tombol slide untuk melihat tutorial selanjutnya.

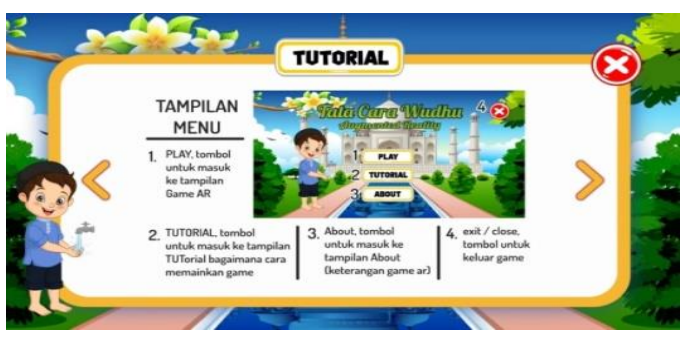

Gambar 25. Tampilan Menu Tutorial

\section{c. Tampilan Menu About}

Pada tampilan ini terdapat informasi tentang aplikasi augmented reality tata cara wudhu.

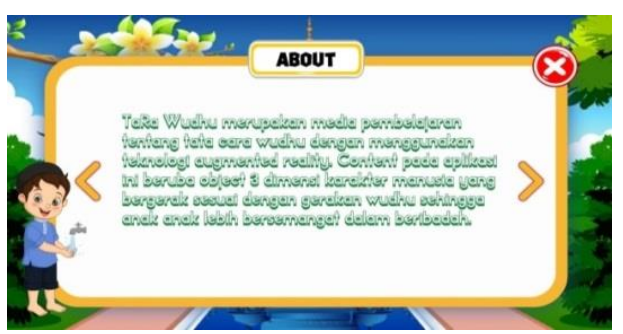

Gambar 26. Tampilan Menu About

\section{d. Tampilan Augmented Reality (AR)}

Pada tampilan ini kamera smartphone di fokuskan pada gambar marker agar mampu membaca marker yang telah dibuat sehingga dapat memunculkan objek 3 dimensi beserta animasi gerakan, teks dan suara. Pada tampilan ini terdapat tombol sound yang digunakan untuk memunculkan suara tentang informasi gerakan wudhu. Tombol exit atau gambar $\mathrm{X}$ yang digunakan untuk kembali ke menu sebelumnya.

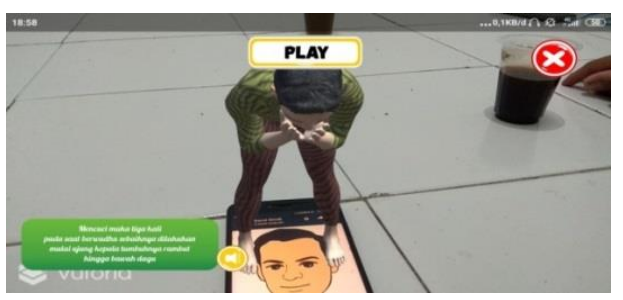

Gambar 27. Tampilan Augmented Reality (AR) Model 3D

\section{e. Pembuatan Katalog}

Pada proses pembuatan katalog ini menggunakan software Corel Draw yaitu sebuah aplikasi desain grafis yang mempermudah pengguna dalam membuat poster, gambar, dan konten lainnya seperti pada gambar 28.

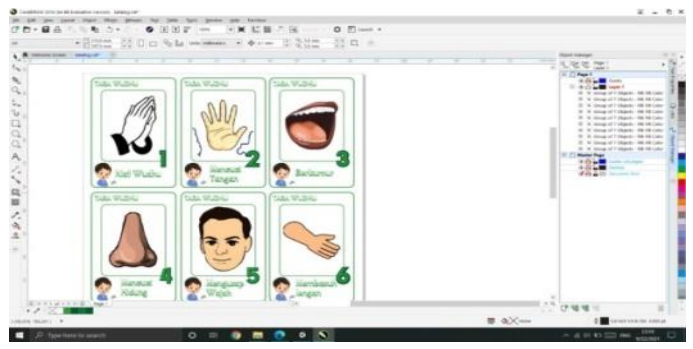

Gambar 28. Pembuatan Katalog

\subsection{Testing (Pengujian)}

Tahap pengujian ini dilakukan hasil pembuatan aplikasi Auggmented Reality ini sesuai atau tidak dengan rancangan yang telah di buat. Pengujian dilakukan dengan menggunakan teknik Black Box. Black Box testing adalah dimana pengujian aplikasi yang dilakukan hanya mengamati hasil eksekusi melalui data uji dan memeriksa fungional dari perangkat lunak. Tahap ini akan menguji fungsionalitas pada fitur-fitur yang disediakan oleh aplikasi. Hasil pengujian fungsional aplikasi dapat di lihat pada tabel 2. Dapat disimpulkan bahwa pengujian fungsional aplikasi berjalan dengan baik sesuai keinginan yang di harapkam.

Setelah pengujian fungsional, langkah berikutnya yaitu pengujian Operation Processing aplikasi tata cara wudhu Augmented Reality. Pengujian ini dilakukan untuk menentukan perbedaan respon time pada beberapa device smartphone yang berbeda. Proses ini dilakukan saat loading kamera smartphone, sehingga jika aplikasi dijalankan pada device yang berbeda dan spesifikasi yang berbeda pula pada smartphone maka, hasil dari respon time juga akan berbeda. Spesifikasi pengujian aplikasi ini dilakukan pada 3 device yaitu dapat dilihat pada tabel 3 .

Hasil dari pengujian Operation Processing kamera smartphone pada beberapa device dapat dilihat pada tabel 4. Kesimpulannya semakin tinggi spesifikasi device yang digunakan maka 
semakin cepat pula respon time loading kamera ketika aplikasi digunakan.

Tabel 2. Hasil pengujian fungsionalitas aplikasi Tata Cara Wudhu AR

\begin{tabular}{|c|c|c|c|c|}
\hline $\begin{array}{l}\mathrm{N} \\
\mathrm{O}\end{array}$ & $\begin{array}{l}\text { Skena } \\
\text { rio }\end{array}$ & $\begin{array}{l}\text { Hasil Yang } \\
\text { diharapkan }\end{array}$ & $\begin{array}{l}\text { Hasil } \\
\text { Penguji } \\
\text { an }\end{array}$ & $\begin{array}{l}\text { Kesi } \\
\text { mpul } \\
\text { an }\end{array}$ \\
\hline 1 & $\begin{array}{l}\text { Install } \\
\text { Apk }\end{array}$ & $\begin{array}{l}\text { Proses } \\
\text { instalasi } \\
\text { apliksai } \\
\text { terpasang } \\
\text { dengan } \\
\text { baik pada } \\
\text { smartphon } \\
\text { e android }\end{array}$ & $\begin{array}{l}\text { Sesuai } \\
\text { harapan }\end{array}$ & Valid \\
\hline 2 & $\begin{array}{l}\text { Menja } \\
\text { lanka } \\
\mathrm{n} \\
\text { aplika } \\
\text { si } \\
\text { yang } \\
\text { telah } \\
\text { di } \\
\text { install }\end{array}$ & $\begin{array}{l}\text { Aplikasi } \\
\text { dapat } \\
\text { berjalan } \\
\text { dengan } \\
\text { baik }\end{array}$ & $\begin{array}{l}\text { Sesuai } \\
\text { harapan }\end{array}$ & Valid \\
\hline 3 & $\begin{array}{l}\text { Melet } \\
\text { akan } \\
\text { marke } \\
\text { r di } \\
\text { depan } \\
\text { kamer } \\
\text { a } \\
\text { Smart } \\
\text { phone }\end{array}$ & $\begin{array}{l}\text { Marker } \\
\text { terlihat } \\
\text { dengan } \\
\text { jelas dan } \\
\text { pendeteksi } \\
\text { an marker } \\
\text { dapat } \\
\text { memuncul } \\
\text { kan objek } \\
\text { 3D }\end{array}$ & $\begin{array}{l}\text { Sesuai } \\
\text { harapan }\end{array}$ & Valid \\
\hline 4 & $\begin{array}{l}\text { Pende } \\
\text { teksia } \\
\mathrm{n} \\
\text { marke } \\
\mathrm{r} \text { yang } \\
\text { berbe } \\
\mathrm{da}\end{array}$ & $\begin{array}{l}\text { Object 3D } \\
\text { muncul } \\
\text { sesuai } \\
\text { dengan } \\
\text { marker }\end{array}$ & $\begin{array}{l}\text { Sesuai } \\
\text { harapan }\end{array}$ & Valid \\
\hline 5 & $\begin{array}{l}\text { Pende } \\
\text { teksia } \\
\mathrm{n} \\
\text { marke } \\
\mathrm{r} \\
\text { untuk } \\
\text { mena } \\
\text { mpilk } \\
\text { an } \\
\text { object } \\
\text { 3D } \\
\text { manus }\end{array}$ & $\begin{array}{l}\text { Object 3D } \\
\text { manusia } \\
\text { beserta } \\
\text { animasi, } \\
\text { teks, dan } \\
\text { suara } \\
\text { muncul } \\
\text { sesuai } \\
\text { dengan } \\
\text { marker }\end{array}$ & $\begin{array}{l}\text { Sesuai } \\
\text { harapan }\end{array}$ & Valid \\
\hline
\end{tabular}

\begin{tabular}{|c|c|c|c|c|}
\hline & $\begin{array}{l}\text { ia } \\
\text { besert } \\
\text { a } \\
\text { anima } \\
\text { si, } \\
\text { teks } \\
\text { dan } \\
\text { suara }\end{array}$ & & & \\
\hline 6 & $\begin{array}{l}\text { Mema } \\
\text { stikan } \\
\text { tombo } \\
1 \\
\text { tutoria } \\
1 \\
\text { berfun } \\
\text { gsi } \\
\text { degan } \\
\text { baik }\end{array}$ & $\begin{array}{l}\text { Jika } \\
\text { ditekan } \\
\text { tombol } \\
\text { turorial } \\
\text { maka } \\
\text { tampilan } \\
\text { layar akan } \\
\text { menunjuka } \\
\text { n tampilan } \\
\text { informasi } \\
\text { tutorial } \\
\text { cara } \\
\text { penggunaa } \\
\text { n aplikasi }\end{array}$ & $\begin{array}{l}\text { Sesuai } \\
\text { harapan }\end{array}$ & Valid \\
\hline 7 & $\begin{array}{l}\text { Mema } \\
\text { stikan } \\
\text { tombo } \\
1 \text { back } \\
\text { (kemb } \\
\text { ali) } \\
\text { berfun } \\
\text { gsi } \\
\text { denga } \\
\text { n baik }\end{array}$ & $\begin{array}{l}\text { Jika } \\
\text { ditekan } \\
\text { tombol } \\
\text { back } \\
\text { (kembali) } \\
\text { maka } \\
\text { tampilan } \\
\text { akan } \\
\text { kembali ke } \\
\text { menu } \\
\text { sebelumny } \\
\text { a tanpa ada } \\
\text { kesalahan }\end{array}$ & $\begin{array}{l}\text { Sesuai } \\
\text { harapan }\end{array}$ & Valid \\
\hline 8 & $\begin{array}{l}\text { Mema } \\
\text { stikan } \\
\text { tombo } \\
1 \text { slide } \\
\text { pada } \\
\text { tampil } \\
\text { an }\end{array}$ & $\begin{array}{l}\text { Jika } \\
\text { tombol } \\
\text { slide di } \\
\text { tekan maka } \\
\text { akan } \\
\text { menampilk } \\
\text { an gambar } \\
\text { petunjuk } \\
\text { lainnya } \\
\text { tentang } \\
\text { penggunaa } \\
\text { n aplikasi }\end{array}$ & $\begin{array}{l}\text { Sesuai } \\
\text { harapan }\end{array}$ & Valid \\
\hline 9 & $\begin{array}{l}\text { Mema } \\
\text { stikan } \\
\text { tombo } \\
1 \\
\text { about } \\
\text { (tenta } \\
\text { ng) }\end{array}$ & $\begin{array}{l}\text { Jika } \\
\text { ditekan } \\
\text { tombol } \\
\text { about } \\
\text { maka } \\
\text { tampilan } \\
\text { akan } \\
\text { muncul }\end{array}$ & $\begin{array}{l}\text { Sesuai } \\
\text { harapan }\end{array}$ & Valid \\
\hline
\end{tabular}




\begin{tabular}{|l|l|l|l|l|}
\hline & $\begin{array}{l}\text { berfun } \\
\text { gsi } \\
\text { denga } \\
\text { n baik }\end{array}$ & $\begin{array}{l}\text { mengenai } \\
\text { informasi } \\
\text { tentang } \\
\text { aplikasi }\end{array}$ & & \\
\hline 1 & Mema & Jika & Sesuai & Valid \\
0 & stikan & ditekan & harapan & \\
& tombo & tombol exit & & \\
& $\begin{array}{l}\text { 1 exit } \\
\text { (kelua }\end{array}$ & maka akan & & \\
& keluar dari & & \\
& aplikasi & & \\
berfun & & & & \\
gsi & & & \\
\hline
\end{tabular}

Tabel 3. Spesifikasi Device Pengujian Aplikasi

\begin{tabular}{|c|c|c|c|c|}
\hline No & $\begin{array}{l}\text { Spesifi } \\
\text { kasi }\end{array}$ & $\begin{array}{l}\text { Xiaomi } \\
\text { Redmi } \\
\text { Note } 4 \mathrm{X}\end{array}$ & $\begin{array}{l}\text { Oppo } \\
\text { F11 } \\
\text { Pro }\end{array}$ & $\begin{array}{l}\text { Vivo } \\
\text { Y20 }\end{array}$ \\
\hline 1 & RAM & $3 \mathrm{~Gb}$ & $6 \mathrm{~Gb}$ & $4 \mathrm{~Gb}$ \\
\hline 2 & $\begin{array}{l}\text { OS } \\
\text { Androi } \\
\text { d }\end{array}$ & $\begin{array}{l}\text { Android } \\
7.0 \\
\text { (Nougat } \\
\text { ) }\end{array}$ & $\begin{array}{l}\text { Androi } \\
\text { d } 9.0 \\
\text { (Pie) }\end{array}$ & $\begin{array}{l}\text { Andr } \\
\text { oid } \\
11.0 \\
\text { (Funt } \\
\text { ouch) }\end{array}$ \\
\hline 3 & $\mathrm{CPU}$ & $\begin{array}{l}\text { Octa- } \\
\text { core } \\
\text { Max 2,0 } \\
\text { GHz } \\
\text { Cortex- } \\
\text { A53 }\end{array}$ & $\begin{array}{l}\text { Octa- } \\
\text { core } \\
(4 \times 2.0 \\
\text { Ghz } \\
\text { Cortex- } \\
\text { A53) }\end{array}$ & $\begin{array}{l}\text { Octa- } \\
\text { core } \\
(4 \times 2 . \\
35 \\
\text { GHz } \\
\text { Corte } \\
x \\
\text { A53) }\end{array}$ \\
\hline 4 & $\begin{array}{l}\text { Chipse } \\
\mathrm{t}\end{array}$ & $\begin{array}{l}\text { Qualco } \\
\text { mm } \\
\text { MSM89 } \\
53 \\
\text { Snapdra } \\
\text { gon } 625\end{array}$ & $\begin{array}{l}\text { Mediat } \\
\text { ek } \\
\text { MT677 } \\
1 \text { Helio } \\
\text { P70 }\end{array}$ & $\begin{array}{l}\text { Medi } \\
\text { atek } \\
\text { MT6 } \\
765 \\
\text { Helio } \\
\text { p35 }\end{array}$ \\
\hline 5 & Gpu & $\begin{array}{l}\text { Adreno } \\
506\end{array}$ & $\begin{array}{l}\text { Mali- } \\
\text { G72 } \\
\text { MP3 }\end{array}$ & $\begin{array}{l}\text { Powe } \\
\text { rVR } \\
\text { GE83 } \\
20\end{array}$ \\
\hline 6 & $\begin{array}{l}\text { Camer } \\
\text { a }\end{array}$ & $13 \mathrm{MP}$ & $\begin{array}{l}48 \mathrm{Mp} \\
+5 \mathrm{Mp}\end{array}$ & $\begin{array}{l}13 \\
\mathrm{Mp}+ \\
2 \mathrm{Mp} \\
+ \\
2 \mathrm{Mp}\end{array}$ \\
\hline
\end{tabular}

Tabel 4. Hasil Pengujian Operation Processing Aplikasi

\begin{tabular}{|c|c|c|c|c|}
\hline No & $\begin{array}{l}\text { Operation } \\
\text { Processin } \\
\mathrm{g}\end{array}$ & $\begin{array}{l}\text { Xiomi } \\
\text { Redmi } \\
\text { Note } \\
4 x \\
\end{array}$ & $\begin{array}{l}\text { Oppo } \\
\text { F11 } \\
\text { Pro }\end{array}$ & $\begin{array}{l}\text { Vivo } \\
\text { Y20 }\end{array}$ \\
\hline 1 & $\begin{array}{l}\text { Loading } \\
\text { awal } \\
\text { aplikasi }\end{array}$ & Lancar & $\begin{array}{l}\text { Lanc } \\
\text { ar }\end{array}$ & $\begin{array}{l}\text { Lanc } \\
\text { ar }\end{array}$ \\
\hline 2 & $\begin{array}{l}\text { Resolusi } \\
\text { tampilam } \\
\text { aplikasi }\end{array}$ & $\begin{array}{l}\text { Tampil } \\
\text { an } \\
\text { aplikas } \\
\text { i sesuai }\end{array}$ & $\begin{array}{l}\text { Tamp } \\
\text { ilan } \\
\text { aplik } \\
\text { asi } \\
\text { terlal } \\
\text { u } \\
\text { panja } \\
\text { ng } \\
\text { batas } \\
\text { atas } \\
\text { dan } \\
\text { bawa } \\
\text { h } \\
\text { terlal } \\
\text { u } \\
\text { sempi } \\
\text { t }\end{array}$ & $\begin{array}{l}\text { Tamp } \\
\text { ilan } \\
\text { aplik } \\
\text { asi } \\
\text { terlal } \\
\text { u } \\
\text { panja } \\
\text { ng } \\
\text { batas } \\
\text { atas } \\
\text { dan } \\
\text { bawa } \\
\text { h } \\
\text { terlal } \\
\text { u } \\
\text { sempi } \\
\text { t }\end{array}$ \\
\hline 3 & $\begin{array}{l}\text { Proses } \\
\text { pendeteks } \\
\text { ian } \\
\text { marker }\end{array}$ & Lancar & $\begin{array}{l}\text { Lanc } \\
\text { ar }\end{array}$ & $\begin{array}{l}\text { Lanc } \\
\text { ar }\end{array}$ \\
\hline 4 & $\begin{array}{l}\text { Proses } \\
\text { rendering } \\
\text { object 3D } \\
\text { karakter } \\
\text { dan } \\
\text { animasi }\end{array}$ & $\begin{array}{l}\text { Lancar } \\
\text { dan } \\
\text { halus }\end{array}$ & $\begin{array}{l}\text { Lanc } \\
\text { ar } \\
\text { dan } \\
\text { sanga } \\
\mathrm{t} \\
\text { halus }\end{array}$ & $\begin{array}{l}\text { Lanc } \\
\text { ar } \\
\text { dan } \\
\text { sanga } \\
\mathrm{t} \\
\text { halus }\end{array}$ \\
\hline 5 & $\begin{array}{l}\text { Loading } \\
\text { saat } \\
\text { kembali } \\
\text { ke menu } \\
\text { sebelumn } \\
\text { ya }\end{array}$ & Lancar & $\begin{array}{l}\text { Lanc } \\
\text { ar }\end{array}$ & $\begin{array}{l}\text { Lanc } \\
\text { ar }\end{array}$ \\
\hline
\end{tabular}

Tabel 5. Hasil Pengujian Layar Aplikasi

\begin{tabular}{|c|c|c|c|c|}
\hline No & Proses & $\begin{array}{l}\text { Xiaom } \\
\text { i } \\
\text { Redmi } \\
\text { Note } \\
4 x\end{array}$ & $\begin{array}{l}\text { Oppo } \\
\text { F11 } \\
\text { Pro }\end{array}$ & $\begin{array}{l}\text { Vivo } \\
\text { Y20 }\end{array}$ \\
\hline 1 & $\begin{array}{l}\text { Menu } \\
\text { utama }\end{array}$ & 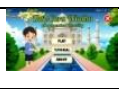 & bi & geted \\
\hline 2 & Tutoria & 1. & 12 & $r=4$ \\
\hline 3 & About & & $r$ & \\
\hline
\end{tabular}




\begin{tabular}{|l|l|l|l|l|}
\hline 4 & $\begin{array}{l}\text { Object } \\
\text { karakte } \\
\text { r AR }\end{array}$ & A & A \\
\hline
\end{tabular}

\subsection{Distribution (Distribusi)}

Setelah proses pengujian dilakukan dan hasil dari proses pengujian berjalan dengan baik maka, dapat dilanjukan pada tahapan terakhir metode Mutlimedia Development Life Cycle yaitu distribution atau distribusi. Pada tahapan ini aplikasi akan di distribusikan melalui penyimpanan google drive dengan link sebagai berikut :

https://drive.google.com/drive/folders/18MT8 2spds2W60o cBeKg13w9cwG74Q -

?usp=sharing

\section{KESIMPULAN DAN SARAN}

\subsection{Kesimpulan}

Bedasarkan hasil analisa dari proses pengujian pada aplikasi Augmented Reality (AR) tata cara wudhu, dapat di simpulkan sebagai berikut :

a. Pendeteksian marker berjalan dengan baik dan dapat memunculkan objek 3D serta gerakan animasi tata cara wudhu, teks, dan suara pada aplikasi.

b. Penerapan teknologi Augmented Reality pada aplikasi tata cara wudhu ini berjalan sesuai perencaaan, dengan menggabungkan Object 3D yang mampu bergerak ke dalam dunia nyata.

c. Aplikasi dapat digunakan sebagai metode pembelajaran pada anak-anak maupun orang dewasa, karena wudhu merupakan kewajiban dalam melakukan ibadah dalam agama islam.

\subsection{Saran}

Penelitian ini masih memiliki kekurangan pada fitur fitur animasi. Saran untuk pengembangan aplikasi lebih lanjut yaitu :

a. Untuk perancangan berikutnya dapat menambahkan object 3D air yang mampu bergerak sehingga tampilan seperti nyata. b. Aplikasi tata cara wudhu ini dapat di kembangkan kembali dengan menambahkan materi tentang tata cara wudhu menggunakan pasir atau debu.

\section{DAFTAR PUSTAKA}

[1]. Erwin Setiawan, Undang Syaripudin, Yana Aditya Gerhana, Implementasi Teknologi Augmented Reality Pada Buku Panduan Wudhu Berbasis Mobile Android, (JOIN) ISSN 2527-9165 Vol.1 No.1, Juni 2016.

[2] Victor Waeo, Arie S.M Lumenta, Brave A. Sugiarso, Implementasi Gerakan Manusia Pada Animasi 3D Menggunakan Metode Pose to pose, E-journal Teknik Informatika, Vol.9, No.1, 20016, ISSN : 23018364.

[3] Andi Apriansyah, Dhimas Mulia Anugraha, Galuh Prakoso, Kevin Nuardy Erdiham, Rudi Priyana, Aplikasi Penganalan Hewan dengan Teknologi Marker Less Augmented Reality Berbasis Android, Journal of Computer and Information Technology, E-ISSN: 2579-5317, Vol.1, No.1 Agustus 2017.

[4] Azalia Ananda Arinal, Virginia Tulenan, Agustinus Jacobus, Pengembangan Aplikasi Tata Cara Wudhu Menggunakan Metode Markerless Augmented Reality, Jurnal Teknik Informatika Vol.14, No.2 AprilJuni 2019, ISSN: 2301-8402.

[5] I Dewa Gede Wahya Dhiyatmika, I Ketut Gede Darma Putra, Ni Made Ika Marini, Mandenni, Aplikasi Augmented Reality, Magic Book Pengenalan Binatang untuk Siswa TK, Lontar Komputer, Vol.6, No.2, Agustus 2015 ISSN: 2088-1541.

[6] Rohmat Indra Borman, Ansori, Implementasi Augmented Reality Pada Aplikasi Android Pengenalan Gedung Pemerintahan Kota Bandar Lampung, JURNAL TECNOINFO, Vol.11, No.1, 2017, ISSN 1693 0010 
[7] Luthfi Rahman, Aghus Sofwan, Yuli Chriistyono, Implementasi Teknologi Augmented Reality Sebagai Panduan Shalat Berbasis Sistem Operasi Android, TRANSMISI, 19, (2), April 2017, e-ISSN 2407-6422.

[8] R dimas Yusuf Wiguna, Pengenalan Alat Musik Tradisional Indonesia Menggunakan Augmented Reality, Jurnal Mahasiswa Teknik Informatika, Vol.3, No.1, Maret 2019.

[9] Muhammad Rifa'I, Tri Listyorini, Anastasya, Latubessy, Penerapan Teknologi Augmented Reality Pada Plikasi Katalog Rumah Berbasis Android, Prosiding SNATIF Ke-1 Tahun 2014, ISBN: 978-602-118004-4.

[10] Victor Waeo, Arie S.M. Lumenta, Brave A. Sugiarso, Implementasi Gerakan Manusia Pada Animasi 3D Dengan Menggunakan Metode Pose to Pose, E-journal Teknik Informatika, Vol.9, No.1, 2016, ISSN : 23018364.

[11] Atmoko Nugroho, Basworo Ardi Pramono, Aplikasi Mobile Augmented Reality Berbasis Vuforia dan Unity Pada Pengenalan Objek 3D Dengan Studi Kasus Gedung M Universitas Semarang,

JURNAL TRANSFORMATIKA, Vol.14, No.2, Januari 2017.

[12] Arista Prasetyo Adi, CorelDraw untuk segala Desain, PT Elex Media Komputindo, Semarang, 2017.

[13] Jubilee Enterprise, Blender untuk Pemula, PT Elex Media Komputindo, Yogyakarta, 2016. 